\title{
Spatial distribution of anthropogenic impurities from large stationary sources in the Baikal Natural Territory on the coast of Lake Baikal
}

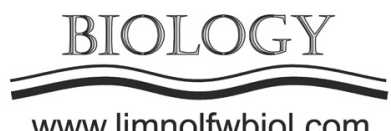

www.limnolfwbiol.com

\author{
Molozhnikova Ye.V.*, Netsvetaeva O.G., Golobokova L.P., Shikhovtsev M.Yu., \\ Nosova V.V., Khodzher T.V.
}

Limnological Institute, Siberian Branch of the Russian Academy of Sciences, Ulan-Batorskaya str., 3, Irkutsk, 664033, Russia

\begin{abstract}
This work presents the chemical composition of snow from the Baikal region in 2019. We analyzed snow sampled along the Irkutsk-Listvyanka highway, in the delta of the Selenga River and the Baikal State Nature Biosphere Reserve. We studied the spatial distribution of sulfates and nitrates from large industrial centres in the south of the Irkutsk Region and the Republic of Buryatia along the direction of the prevailing air mass transport. We determined the factors that affect the change in the chemical composition of snow waters both in quantitative and qualitative terms. Using the calculations of dispersal of anthropogenic impurities from large source cities (HSPLIT), we determined the percentage of adverse meteorological situations, during which emissions from regional anthropogenic sources can reach the coast of Lake Baikal. The study aimed to update the information about the effect of large objects of atmospheric pollution located in the Baikal Natural Territory on the chemical composition of the atmosphere in the Baikal region.
\end{abstract}

Keywords: Dispersion of anthropogenic pollutants, snow cover, air mass trajectories, sulfates, nitrates.

\section{Introduction}

Large coal power plants having high pipes of up to $100-200 \mathrm{~m}$ are the main source of atmospheric emissions of pollutants in large cities of Siberia. Taking into account the heating of flue gases, the actual height of the flare can reach $300-500 \mathrm{~m}$. This contributes to the distribution of emitted impurities over significant distances from the sources (Obolkin et al., 2014). Northwestern and southeastern winds are prevailing in the Baikal region. Thus, with northwestern winds, some atmospheric emissions from large power plants located near the cities of Irkutsk and Angarsk can reach the basins of Southern and Central Baikal (Obolkin et al., 2016). With the southeastern winds, the sources located in the Republic of Buryatia will have the greatest influence. The simplest method for assessing the spatial extent of this transport is the analysis of anthropogenic tracers in snow.

\section{Material and methods}

To study the nature and extent of the transport of pollutants from large industrial sources in the south of the Irkutsk Region and the Republic of Buryatia, snow was investigated in early March 2019. Samples were taken along the main air mass transport from industrial objects in the region to the water area of the lake. Sampling was carried out along the Irkutsk-Listvyanka highway (nine snow samples), in the Baikal State Nature Biosphere Reserve (five snow samples) and the delta of the Selenga River (six snow samples). Sulfates and nitrates, the main transformation components of atmospheric emissions of sulfur and nitrogen oxides, were chosen as indicators of the impact of large power plants on the environment in the Baikal Region.

To determine the recurrence of adverse meteorological situations that contribute to the dispersal of emissions from large regional sources above the water area of Lake Baikal, direct trajectories of air mass movement were calculated (Hybrid Single Particle Lagrangian Integrated Trajectory Model, HSPLIT) (Draxler). For each of the four winter months (from November 2018 to February 2019), 240 direct trajectories of air mass movement from the main source cities were constructed.

\section{Results and discussion}

Analysis of the chemical composition of snow revealed that the greatest accumulation of sulfates was in snow located near the sources (Fig. 1A, 1C). A high level of sulfate accumulation was also at the sampling

*Corresponding author.

E-mail address: yelena@lin.irk.ru (Y.V. Molozhnikova)

(C) Author(s) 2020. This work is distributed under the Creative Commons Attribution 4.0 License. 


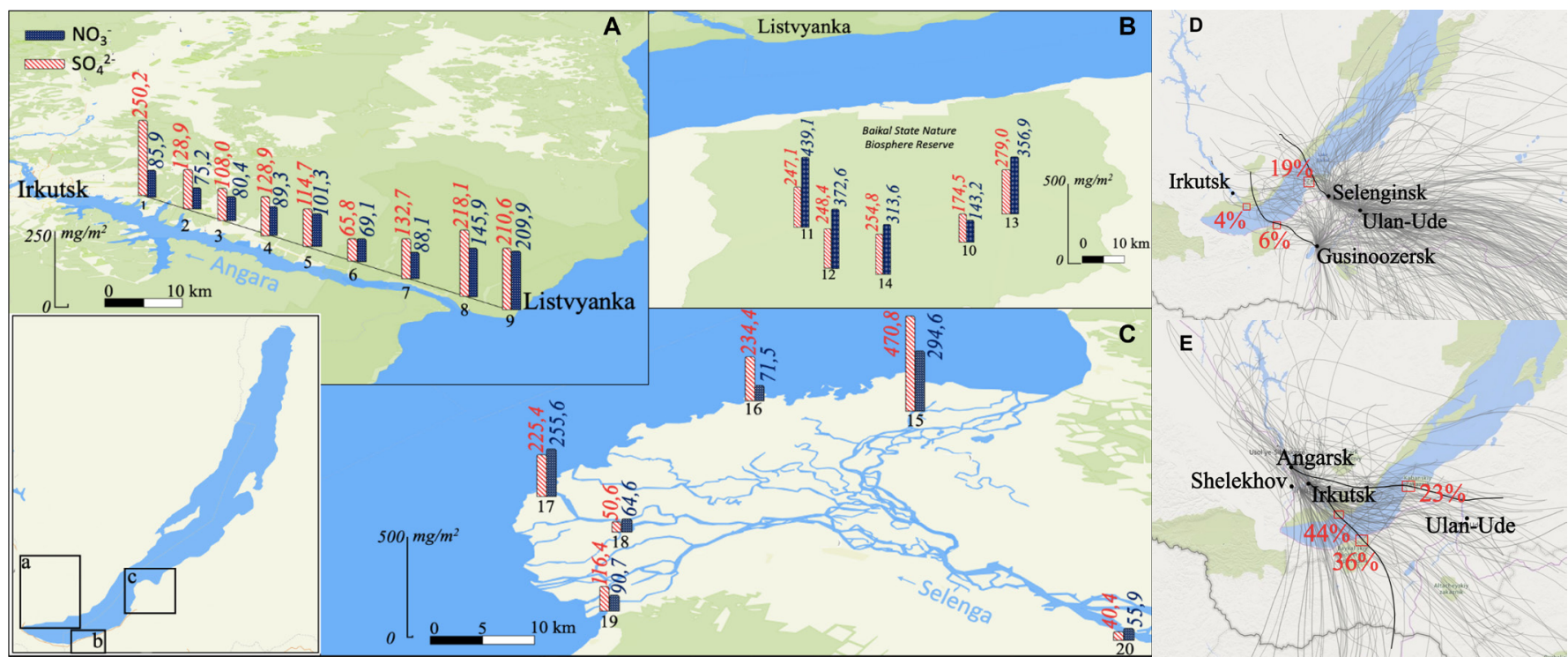

Fig.1. Map of spatial distribution of anthropogenic impurities in the Baikal Region: A, B, C) accumulation of sulfates and nitrates in snow, $\mathrm{mg} / \mathrm{m} 2 ; \mathrm{D}, \mathrm{E})$ percentage distribution of direct trajectories of air mass movement from the main source cities (250, $500 \mathrm{~m}$ above ground level (AGL)) calculated for the winter of 2018-2019: https://www.ready.noaa.gov/HYSPLIT.php.

sites (10-14 and 15), which is due to the high snow cover. On the contrary, nitrates tended to increase with distance from the sources of atmospheric emissions (Fig. 1A, 1B, 1C), and the highest accumulation was detected towards the main transport.

Figure $1 \mathrm{~d}$, e shows the percentage distribution of air mass transport to Lake Baikal. The main transport from the sources of the Irkutsk Region is directed to the southeast coast of Lake Baikal. Only a fifth of emissions are transported to the central basin where it is laid on the distribution fields of emission from the sources of Buryatia. In a simultaneous analysis of the chemical composition of snow samples and distribution fields of impurity transport from the sources, the fields of high recurrence of the transport coincided with the sampling sites with high deposition values of indicator substances. Based on this fact, the detected high tracer accumulations in snow are traces of emission plumes from regional heat and power sources.

This study was carried out within the LIN SB
RAS State Task No. 0345-2019-0008 "Assessment and Forecast of Ecological State of Lake Baikal and Adjacent Territories under Conditions of Anthropogenic Impact and Climate Change" and RFBR grant No. 20-45380024 r/a.

\section{References}

Obolkin V.A., Potemkin V.L., Makukhin V.L. et al. 2014. Low-level atmospheric jets as main mechanism of long-range transport of power plant plumes in the Lake Baikal Region. International Journal of Environmental Studies 71: 391-397. DOI: 10.1080/00207233.2014.918396

Obolkin V.A., Khodzher T.V., Sorokovikova L.M. et al. 2016. Effect of long-range transport of sulphur and nitrogen oxides from large coal power plants on acidification of river waters in the Baikal region, East Siberia. International Journal of Environmental Studies 73: 452-461. DOI: 10.1080/00207233.2016.1165481 